PRINT ISSN 1119-8362

Electronic ISSN 1119-8362
Full-text Available Online at

J. Appl. Sci. Environ. Manage. https://www.ajol.info/index.php/jasem Vol. 24 (6) 1041-1044 June 2020 http://ww.bioline.org.br/ja

\title{
Water Level and the Potentials for Wetland Formation and Sustainability in Lower Ogun River Floodplain, Nigeria
}

*OGUNYEMI, IA; OGUNTOKE, O; ADEOFUN, CO

\author{
1Department of Environmental Management and Toxicology, College of Environmental Resources Management, Federal University of \\ Agriculture, Abeokuta, Nigeria \\ *Corresponding Author: Email: essackyy2k3@yahoo.com
}

\begin{abstract}
Identification, delineation and monitoring of wetlands which requires the understanding and application of their ecological characteristics are critical factors in wetland management and conservation. This study assessed the potentials of wetland formation and sustainability in the lower Ogun river basin by determining the levels of surface and ground water. The study area was divided into $1 \mathrm{~km}^{2}$ grids of 67 units using $0.052 \%$ sampling intensity for the assessments in dry and wet seasons. Monthly water table levels were assessed in $50 \mathrm{~cm}$ soil pit while inundation levels were measured during the flooding event using staff gauge. Assessment was carried out for one year during which frequency and periodicity of water table and inundation events were recorded. Results revealed that low water table level ranged from 5 to $45 \mathrm{~cm}$ of soil depth and occurred between August and September within 6 grids. Water table and surface water was recorded within a period of $2-10$ weeks during the rainy season. The peak of water levels coincided with the peak of precipitation $(>200 \mathrm{~mm}$ ) ranging from 30 to $280 \mathrm{~cm}$ between September and October while covering $28.75 \mathrm{~km}^{2}$. Conclusively, surface and groundwater levels were recorded during the rainy season having direct variation with the volume of precipitation for a duration that is long enough to support the formation of wetland hydrophytes and hydric soil.
\end{abstract}

DOI: https://dx.doi.org/10.4314/jasem.v24i6.15

Copyright: Copyright (C) 2020 Ogunyemi et al. This is an open access article distributed under the Creative Commons Attribution License (CCL), which permits unrestricted use, distribution, and reproduction in any medium, provided the original work is properly cited.

Dates: Received: 30 April 2020; Revised: 27 May 2020; Accepted: 19 June 2020

Keywords: Wetlands; Hydrology; Ground water; Surface water; Inundation; Precipitation.

Wetlands are transitional between terrestrial and aquatic systems where the water table is usually at or near the surface, or the land is periodically covered with shallow water, and which land in normal circumstances supports or would support vegetation typically adapted to life in saturated soil (Department for Water Affairs and Forestry, DWAF 2010). Hydrology is considered the master variable of wetland ecosystems, driving the development of wetland soils and leading to the development of the biotic communities, it can determine plant species composition as well as the distribution of species within a wetland, their productivity and capacity for nutrient uptake (Fennessy et al. 2004). Prolonged presence of water in wetlands is a fundamental determinant of soil characteristics and species composition. It describes the patterns of water storage and movement within and across the wetland's boundaries which could have strong seasonal patterns, largely as a result of changing rainfall and sunshine intensity and is said to determine the flora and fauna, biogeochemistry and productivity of wetlands (Greater Wellington Regional Council, GWRC 2005). Alteration of hydrology could lead to the decline and eventual death of wetlands in general. Many areas, like river basins that are presumed to have wetlands because of their proximity to water bodies could lose their wetland status due to hydrological modifications or change in precipitation patters. It is such a critical factor that has great cause and effect consequence as explained by Turner and Lewis (1997) on how about 20 hectares area of mangrove trees were killed when a road was built across a natural channel leading to the gulf of Mexico in Clam Bay, Collier County, Florida. The changes appeared to be due to hydrologic modifications from a road that reduced freshwater fluxes into the area and produced hypersaline conditions that was lethal to mangroves. Similar situations were recorded in Laguna Boca Quebrada, Porto Rico and South Lousiana (Turner and Lewis 1997). The hydrological status of many wetlands are not determined having a reputation based on longstanding assessment or even an assumption. Studies involving the description of wetland hydrological system are important for conservation and easy detection of hydrological modifications which could help in restoration effort in the advent of reconstruction of degraded wetlands. This study 
assessed the potentials of wetland formation and sustainability in the lower Ogun river basin by determining the levels of surface and ground water being the primary ecological drive force.

\section{MATERIALS AND METHODS}

Study area: The Ogun River is within latitudes $6^{\circ} 26^{\prime}$ $\mathrm{N}$ and $9^{\circ} 10^{\prime} \mathrm{N}$ and longitudes $2^{\circ} 28^{\prime} \mathrm{E}$ and $4^{\circ} 8^{\prime} \mathrm{E}$ Southern Nigeria, with about $2 \%$ of the basin in Benin Republic, having a land area of $23,000 \mathrm{Km}^{2}$, with a generally low relief with the gradient in the NorthSouth direction (Bhattacharya and Bolaji, 2010). Opeki and Ofiki Rivers are the main tributaries while Eriti Forest and the banks of Ogun River are the main ecosystems. The study area is a freshwater forested floodplain which is a section of the Lower Ogun River basin. It is located in Obafemi - Owode Local Government Area of Ogun State, Nigeria and which falls in the humid tropical rainforest zone on latitude $6^{\circ} 50^{\prime} \mathrm{N}$ to $7^{\circ} 50^{\prime} \mathrm{N}$ and longitude $3^{\circ} 18^{\prime} \mathrm{E}$ to $3^{\circ} 32^{\prime} \mathrm{E}$ (Fig. 1). It covers an estimated area of $153 \mathrm{Km}^{2}$. The map of the study area was premised on a national baseline survey conducted by Cedar Groove Management Company (CGMC, 2008).

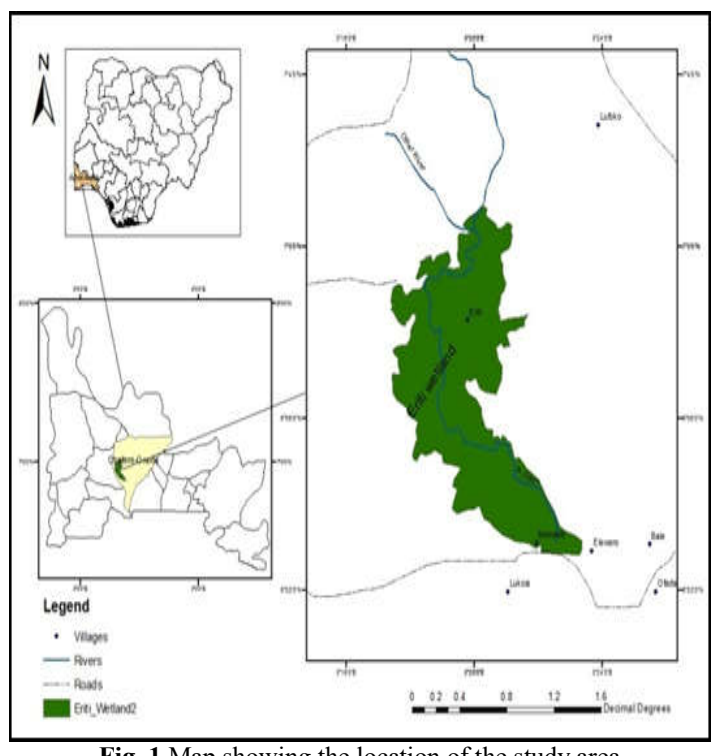

Fig. 1 Map showing the location of the study area

Sampling method: The study area of approximately 67 $\mathrm{Km}^{2}$ was divided into $1 \mathrm{Km}$ by $1 \mathrm{Km}$ Grid (Fig. 2) which gave a total of approximately 67 Grids. Based on a sampling intensity of $0.052 \%$, assessments were carried out within 14 randomly selected grids. Four 25 $\mathrm{m}$ by $25 \mathrm{~m}$ plots were randomly placed within each of the 14 grids where assessments of saturation and inundation were done within each plot. Within each grid, four (4) randomly placed sampling plots were used but where it became necessary due to constraints, initial plot positions were re-adjusted to a new position on the field. Therefore, all assessments were carried out within 56 sample plots of $25 \mathrm{~m} \times 25 \mathrm{~m}$ each.

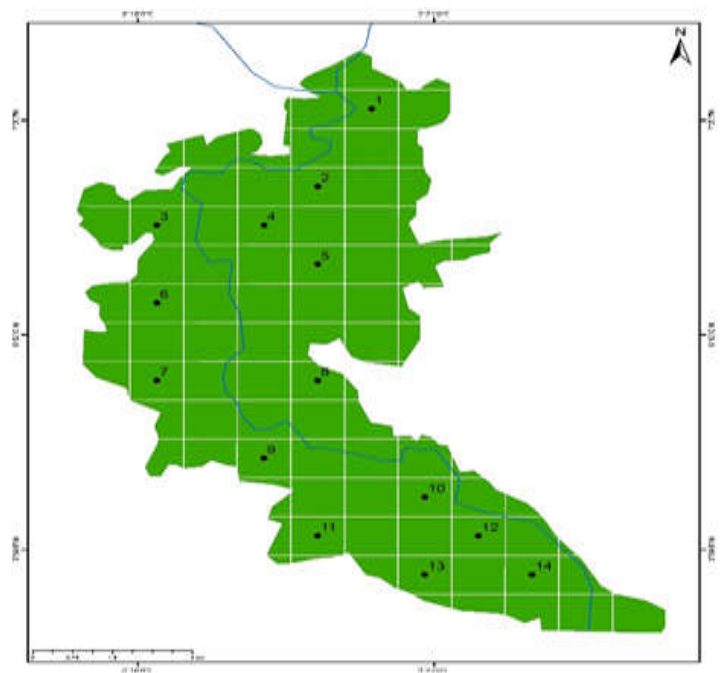

Fig. 2 Randomly selected grids based on $0.052 \%$ sampling intensity

Assessment of Saturation and Inundation: Assessments were carried out in 2016 within 14 randomly selected grids. Within each grid, four (4) sampling plots were randomly selected with a minimum distance of $40 \mathrm{~m}$. However, where it became necessary due to constraints, initial plot positions were re-adjusted to a new position on the field while maintaining the distance. Therefore, all assessments were carried out within 56 sample plots of $25 \mathrm{~m}$ x $25 \mathrm{~m}$ each. Ground water was assessed by digging a soil pit to a depth of $60 \mathrm{~cm}$ and observing the level at which water stands in the hole after sufficient time has been allowed for water to drain into it. In instances where water was observed at the bottom of the hole but has not filled to the top, the side of the hole was examined and the shallowest depth at which water is entering the hole was recorded. Water levels in soil pit were measured with standard $30 \mathrm{~cm}$ ruler and the values were recorded with negative values to differentiate it from surface water values. Sample plots within which water was found at a depth $\leq 50 \mathrm{~cm}$ from the ground level were noted as saturated. This assessment was conducted monthly from January to December. Surface water levels were measured with staff gauge at some accessible locations while the general height and areal extent of inundation was derived by interpolating the measured values for other areas using the interpolation technique of ArcGIS. The duration and frequency of inundation were also recorded. The presence of ground water and or surface water was taken as a positive indicator of wetland hydrology. 
Precipitation data was obtained from secondary data source (Nigerian Meteorological Services) while topography, slope and drainage maps were analysed and generated using hydrogeomorphology tools of ArcGIS 10.0.

\section{RESULTS AND DISCUSSION}

There was no groundwater and surface water in Grids $1,10,12$ and 14 while saturation value of $30 \mathrm{~cm}$ was recorded in Grid 2 in October. Despite a lack of groundwater, Grids 4 and 5 were inundated between September and November with peak inundation values of $12 \mathrm{~cm}$ and $210 \mathrm{~cm}$ respectively occurring in October. Groundwater was observed in August at the depth of $30 \mathrm{~cm}, 20 \mathrm{~cm}$ and $45 \mathrm{~cm}$ within Grids 6,7 and 9 respectively and by September at a depth of $5 \mathrm{~cm}, 40$ $\mathrm{cm}, 40 \mathrm{~cm}$ and $45 \mathrm{~cm}$ within Grids $9,3,8$ and 11 respectively (Fig. 3).

Saturation was overtaken by surface water in October at the heights of $115 \mathrm{~cm}, 192 \mathrm{~cm}, 118 \mathrm{~cm}, 280 \mathrm{~cm}$ and $90 \mathrm{~cm}$ within Grids 6, 7, 8, 9 and 11 respectively. Meanwhile, by November, water levels had dropped significantly where varied levels of groundwater or surface water occurred at $45 \mathrm{~cm}, 46 \mathrm{~cm}, 34 \mathrm{~cm}$ and 42 $\mathrm{cm}$ within Grids 6, 7, 9 and 11 respectively however by December, water levels had dropped deeply below $50 \mathrm{~cm}$ of the soil depth leaving all grids in total dryness as illustrated in Fig. 1 and Plate 1. Surface water analysis showed that Grids 3, 4, 5, 6, 7, 8, 9 and 11 were inundated from September to the end of November from a height of $30 \mathrm{~cm}$ to $280 \mathrm{~cm}$ while interpolation showed that approximately $28.75 \mathrm{Km}^{2}$ $(41.93 \%)$ of the entire study area were also inundated.

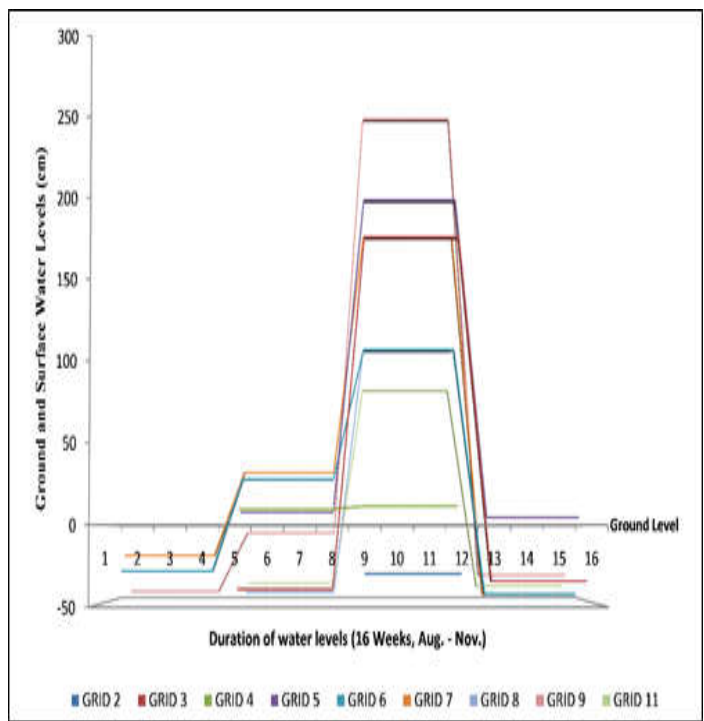

Fig. 3 Hydrograph showing duration of groundwater and surface water levels in Grids
The interpolated extent of surface water is illustrated in Fig. 4. This is similar to the findings of Acreman and Miller (2007) where water discharges from the La Mancha aquifer when groundwater levels are high but when groundwater levels are low the direction of groundwater flow is reversed and water moves downwards from the wetlands to recharge the aquifer. Groundwater and surface water lasted for about sixteen weeks (112 days) which is long enough for the growth of hydrophytic vegetation and development of hydric soil, (USACE ; DWAF, 2010). It is known that during this period, the soil would be subjected to oxidative pressure leading to the formation of gleying or mottles while hydrophytic plant species which are more adapted to the condition will begin to thrive.

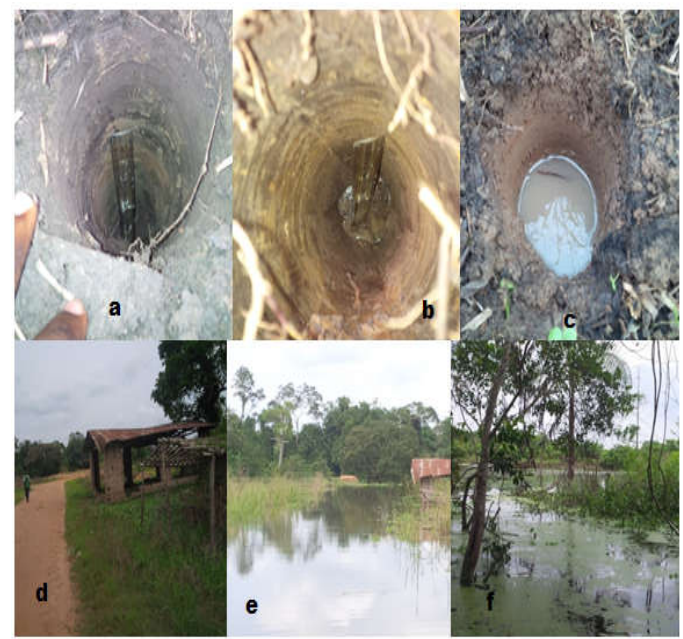

Plate 1 Gradual increase in saturation levels within different grids $(a, b, c)$ and water levels before (d) and during (e and f) inundation

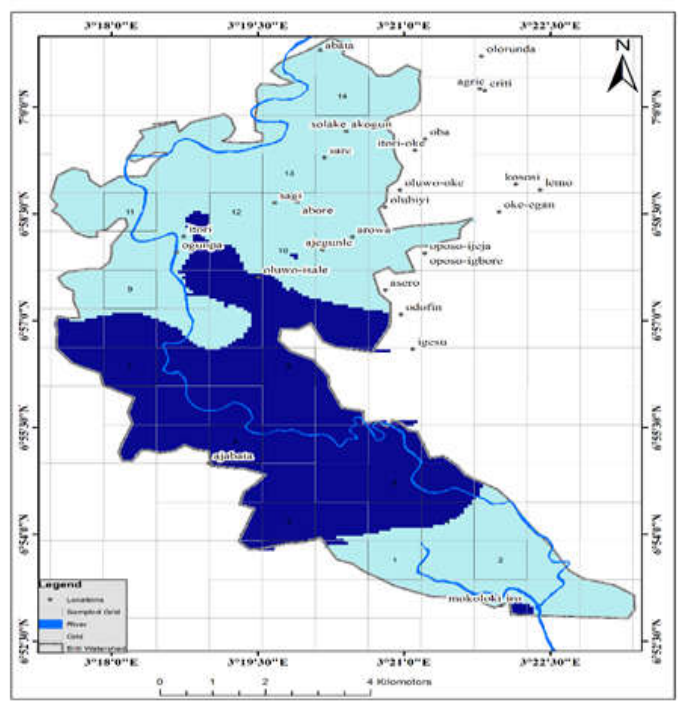

Fig. 4 Map of study area showing extent of flooding (Source: Nigerian Meteorological Services 2017) 
Hydrology was primarily driven by the intensity of precipitation as shown in Fig. 5.

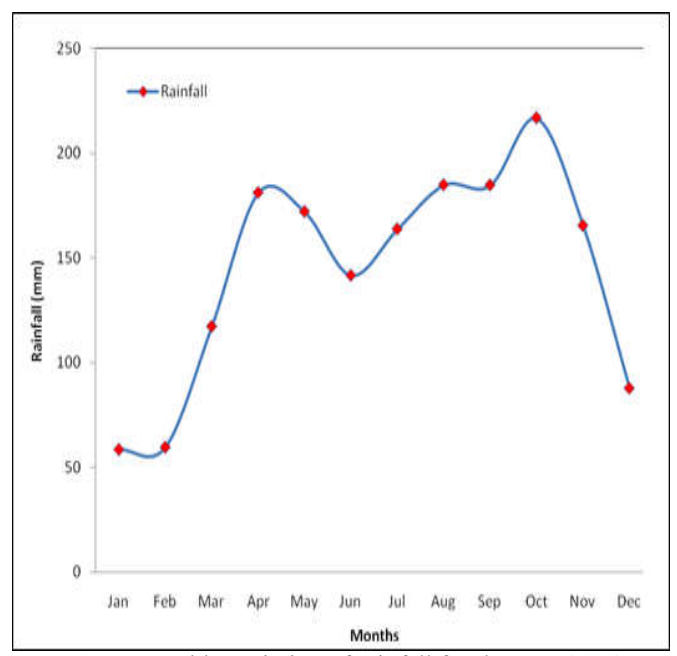

Fig. 5 Monthly variation of rainfall for the year 2016

Groundwater levels were near the surface as precipitation reached about $200 \mathrm{~mm}$ in August. This continued till September when surface waters were recorded in 4 grids due to poor drainage of the area. There was a sharp rise in surface water level reaching up to $280 \mathrm{~cm}$ in a grid. This occurred due to over-bank flow from the river at the peak of rainfall $(225 \mathrm{~mm})$ in October. This implied that the formation and sustenance of wetlands within this river basin largely depends on rainfall pattern and volume. Unlike some wetlands fed by underground water and aquifer, this floodplain is majorly fed by precipitation. The level, extent, timing, frequency and duration of surface and groundwater depends on the intensity and duration of annual rainfall. If the early rain had a higher volume, there was the possibility of having high water table and even surface water as early as April (Fig. 5) within the same year. Also, high groundwater and surface water levels may not exist, unless a high volume of rainfall is recorded. This means that wetland hydrology can be influenced by climate change because in the event of a prolonged dry spell or a period of low rainfall, the wetland soil could become dry and parched. In such situation, hydrophytic species may be succeeded by upland species while wetland fauna might be forced to migrate. If such situation continues, the wetland might be eventually lost.

Conclusion: The study area is a poorly drained flatlowland. The groundwater is rain-fed while most of the surface water through overbank flow is rain-induced. The formation and continued existence of wetlands is contingent on the level and duration of ground and surface water which depends on rainfall. This study finds that with or without flooding, high level of rainfall could be sufficient for wetland development and sustenance in a poorly drained floodplain as opposed to the belief that flooding is necessary.

\section{REFERENCES}

Acreman, MC; Miler, F (2007). Hydrological Impact Assessment of Wetlands. International Centre for Ecology and Hydrology, Wallingford, UK.

Bhattacharya, AK; Bolaji, GA (2010). Fluid Flow Interactions in Ogun River, Nigeria. IJRRAS 2: 173-180.

Cedar Groove Management Consultants (2008). Federal Government of Nigeria: Fadama IICritical Ecosystem Management Report; Strategic and Baseline Studies of Eriti Watersheds, Nigeria.

Department of Water Affairs and Forestry, (2010). A Practical Field Procedure for Idenfication and Delineation of Wetlands and Riparian Areas, Pretoria, Republic of South Africa.

Fennessy, MS; Siobhan, M; Mack, JJ; Rokosch, A; Martin, K; Mick, M (2004). Integrated Wetland Assessment Program Part 5; Biogeochemical and Hydrological Investigations of Natural and Mitigation Wetlands, Columbus, Ohio, USA.

Greater Wellington Regional Council, (2005). Understanding the "Wet" in Wetlands; A Guide to the Management of Freshwater Wetland Hydrology, NZ.

Nigerian Meteorological Services, (2016) Agrometeorological Bulletin, NG.

Turner, RE; Lewis, RR (1997). Hydrologic Restoration of Coastal Wetlands. Wetlands Ecology and Management, 4 (2): 65-72

United States Army Corps of Engineers (2010). Regional Supplement to the Corps of Engineers Wetland Delineation Manual: Midwest Region. In: Wakeley, JS; Lichvar, RW; Noble, CV (eds) Version 2.0. U.S. Army Engineer Research and Development Center, Vicksburg, p.154. 